\title{
Rarity Status Assessments of Bugseeds (Amaranthaceae: Corispermum) in Manitoba
}

\author{
DiANA BIZECKi RoBSON
}

The Manitoba Museum, 190 Rupert Avenue, Winnipeg, Manitoba R3B 0N2 Canada; email: drobson@manitobamuseum.ca

Robson, Diana Bizecki. 2011. Rarity status assessments of bugseeds (Amaranthaceae: Corispermum) in Manitoba. Canadian Field-Naturalist 125(4): 338-352.

To provide a more accurate assessment of the rarity of the plant genus Corispermum (Amaranthaceae), commonly known as bugseeds, in Manitoba, I undertook a survey of all historical populations. In total, 68 quarter sections were selected for presence/absence surveys; 37 of them contained at least one species of bugseed. Only 10 of the 20 historical populations in Manitoba were relocated. The total estimated size of known bugseed populations in Manitoba in 2010-2011 was approximately 9820 to 13060 individuals. American Bugseed (C. americanum (Nutt.) Nutt. var. americanum) is the most abundant and widespread of the bugseeds in Manitoba, followed by Hairy Bugseed (C. villosum Rydb.). There is only one population of Hooker's Bugseed (C. hookeri Mosyakin var. hookeri) in the province. Pallas' Bugseed (C. pallasii Steven) was not relocated and should probably be considered extirpated in Manitoba. The habitats at $61 \%$ of the localities where bugseeds were confirmed are anthropogenically disturbed, the most common habitat being roadsides with exposed bare sand. Of the localities where bugseeds were not relocated, 67\% occurred in natural sandy areas, suggesting that dune stabilization is a major threat to the continuing persistence of these species.

Key Words: Bugseeds, Manitoba, Corispermum americanum var. americanum, Corispermum villosum, Corispermum hookeri var. hookeri, Corispermum pallasii, distribution, habitat, psammophile, status.

Drastic declines in the area of bare sand in major dune fields in western Canada have recently been documented (Hugenholtz and Wolfe 2005; Wolfe and Thorpe 2005). The area of bare sand in the largest dune field in Manitoba, the Brandon Sand Hills, has shrunk by about 50\% since 1950 (Wolfe et al. 2000). As a result of this habitat loss, some psammophilic (sand-loving) plants and animals, including Hairy Prairie Clover (Dalea villosa (Nutt.) Spreng. var. villosa), Smooth Goosefoot (Chenopodium subglabrum (S. Wats.) A. Nels.), Prairie Skink (Plestiodon septentrionalis Baird 1858), and Dusky Dune Moth (Copablepharon longipenne Grote 1882), are considered nationally rare and are now protected under the Species at Risk Act (Government of Canada 2011). Herbarium labels indicate that annual bugseed (Corispermum spp.) plants are also psammophilic, occurring almost exclusively on bare or partially stabilized dunes, or bare, sandy areas created by human activities.

The bugseeds are a genus of annual, ruderal (growing in waste places), herbaceous plants, recently moved to the family Amaranthaceae from the Chenopodiaceae (Chase and Reveal 2009). Plants in this family are often highly stress-tolerant, growing in sandy, calcareous, serpentine, and saline habitats (Robertson and Clemants 2003). Some species are of economic importance because they are edible (e.g., Spinach, Spinacia oleracea L., and Quinoa, Chenopodium quinoa Willd.), weedy (e.g., Russian Thistle, Salsola tragus L., and Redroot Pigweed, Amaranthus retroflexus L.), or ornamental (e.g., Love-lies-bleeding, Amaranthus caudatus L., and cockscomb, Celosia spp.). Bugseeds are widespread in Canada occurring from Vancouver east to the St. Lawrence River in Quebec, and from the shores of Lake Erie in the south to the MacKenzie River in the Northwest Territories (Robson 2010).

I recently examined Canadian herbarium specimens of Corispermum as part of a nomenclatural updating project (Robson 2010) prompted by changes to the taxonomy of this genus (Mosyakin 1995, 2003). During the herbarium research, I determined that four species of bugseeds were historically found in Manitoba (Robson 2010). However, the majority of the specimens (77\%) had been collected prior to 1975 , so up-to-date information on the current distribution and abundance of these species was lacking. Status recommendations using the revised Corispermum herbarium data for both NatureServe $\left(2011^{*}\right)$ and Canadian Endangered Species Conservation Council (2011) ranking systems were recently made in Robson (2010).

The rarity status assessment of species is important, as it provides a snapshot of the health of various ecosystems. Declines in species abundance can indicate that the ecosystems they occur in are under stress and in need of management changes. The objective of this project was to determine the current rarity status of bugseed species in Manitoba by conducting a field study to attempt to relocate all previously identified populations and to assess whether habitat has been lost or altered.

\section{Methods}

Collections at the herbaria in the following institutions were examined (acronyms follow Thiers 2012*): University of British Columbia (UBC), Royal British Columbia Museum (V), University of Alberta (ALTA), University of Calgary (UAC), University of Lethbridge (LEA), Royal Alberta Museum (PMAE), University 
of Saskatchewan (SASK), University of Manitoba (WIN), Manitoba Museum (MMMN), Royal Ontario Museum (TRT), University of Waterloo (WAT), National Collection of Vascular Plants, Agriculture and Agri-Food Canada (DAO), Canadian Museum of Nature (CAN), Université de Montréal (MT), and McGill University (MTMG).

A total of 102 specimens were examined, and the data recorded on the labels were summarized in a spreadsheet; 69 specimens were determined to be locality duplicates. To determine where to conduct the field surveys, I obtained a latitude and longitude for each previously known locality as well as for areas containing open dunes and beaches. Geographic coordinates, either recorded by the original collector or derived from the label information by the staff at the herbaria housing the specimens, were available for 11 of the localities. No geographic coordinate(s) were supplied by the collector for most specimens (89\%). For those localities, the place name on the herbarium label was entered into the Atlas of Canada website (http://atlas.nrcan.gc.ca/site/english/maps/topo/map) search function, and the latitude and longitude were noted. Sometimes detailed locality descriptions (e.g., 5 miles west of Deleau) could be used in conjunction with Atlas of Canada maps to pinpoint a more accurate set of coordinates. The preliminary geographic coordinates used to select the quarter sections for field surveys were only approximate but likely were within a $10-25 \mathrm{~km}$ radius of the historical population. By entering the preliminary geographic coordinates into the Atlas of Canada search function, I could examine satellite maps of the general area where the bugseed specimens had been found in the past. In particular, I searched areas of what appeared to be bare sand and/or native grassland.

A total of 60 quarter sections (approximately 65 ha each) in the most likely areas where bugseeds had been found in the past were selected for surveys. An additional 8 quarter sections containing potential bugseed habitat were also surveyed, for a grand total of 68 . The number of quarter sections searched at each locality is noted in Table 1. The geographic coordinate in Table 1 represents the location of the first Corispermum plant found at each locality or, if Corispermum was not found in the quarter section, the starting point of the field survey at that locality. Using the Committee on the Status of Endangered Wildlife in Canada (COSEWIC) definition of a population as "a geographically or otherwise distinct group within a wildlife species that has little demographic or genetic exchange with other such groups" (COSEWIC 2010*), I determined that the localities occurred in 13 separate populations.

All landowners were contacted to obtain their permission for a site visit. Collection permits for Grand Beach Provincial Park, Patricia Beach Provincial Park, and Spruce Woods Provincial Park were obtained from Manitoba Conservation.

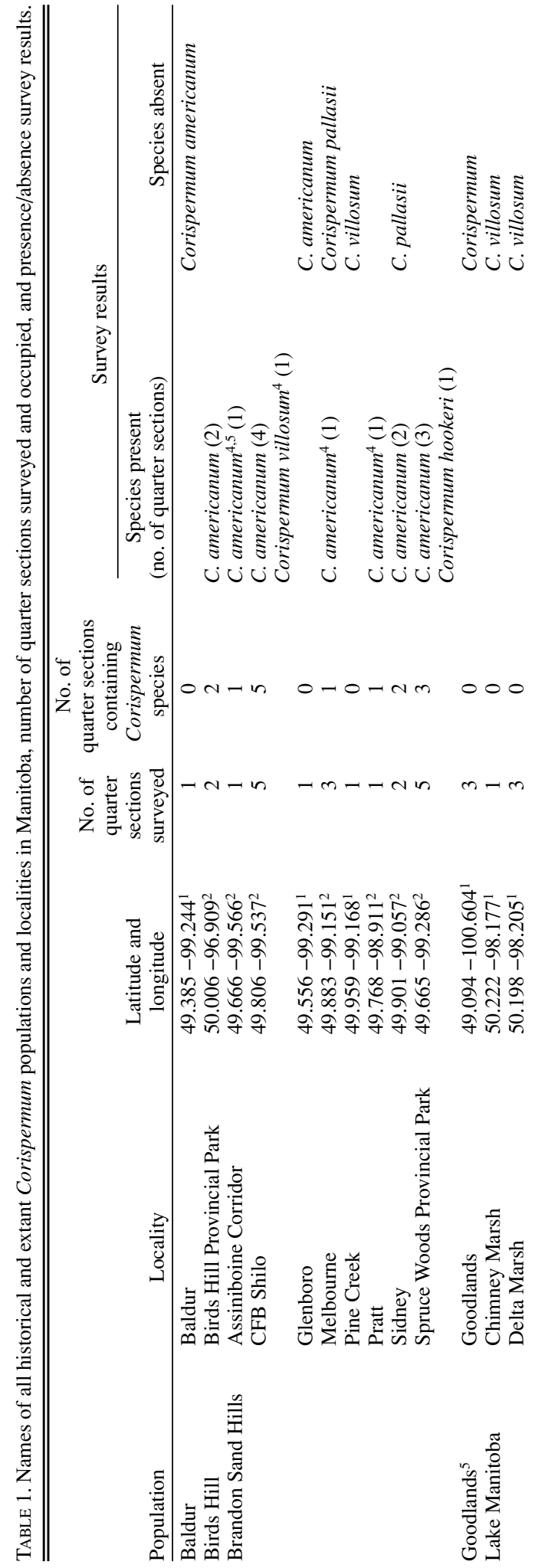




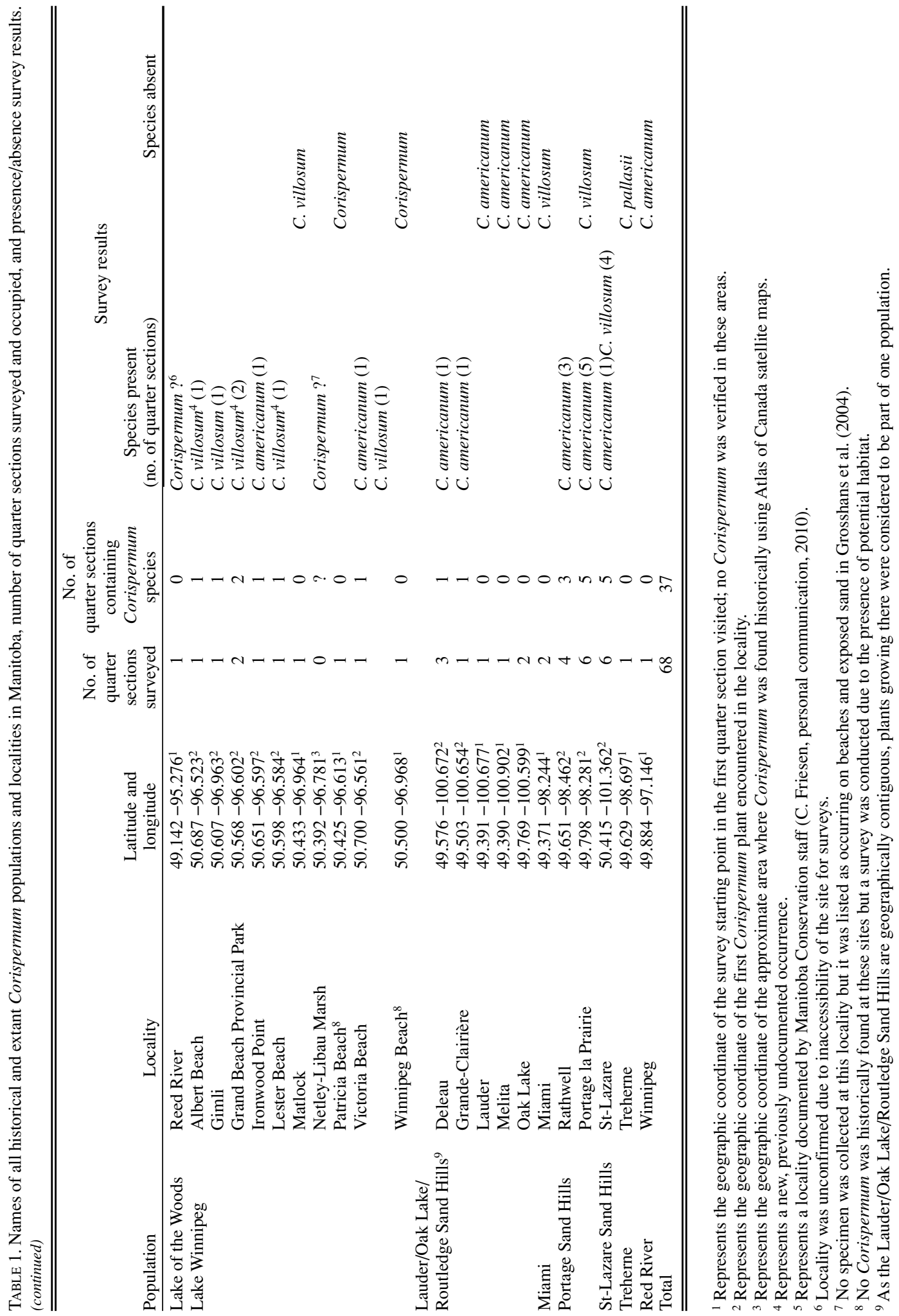


Due to time limitations, only presence/absence surveys were conducted. As most herbarium records indicated that the plants had been growing on bare or disturbed sand, these habitats were examined particularly closely and, in most cases, were selected as the starting point for each survey. Habitats clearly unsuitable for the species (i.e., wetlands, dense aspen bluffs) were avoided in order to increase efficiency. If bugseeds were present, they were typically encountered within the first $10-15$ minutes of searching. In some cases, bugseed plants were found on the public land road allowance, so no survey of the adjacent private property was required to verify the species' presence in that particular quarter section. This means that a large number of the extant populations were noted as occurring along roadsides. More thorough surveys of the occupied quarter sections may reveal that there are additional plants on natural habitats farther from the roads.

The 68 quarter sections in southern Manitoba were visited for a total of 15 days ( 105 hours) split evenly over two years in late August and early September when the plants were in seed. As a fair portion of that time was spent travelling to the sites, only 63 hours (on average 56 minutes per quarter section) was actually spent surveying or recording population and habitat data. Due to flooding in 2011, one locality along Lake Winnipeg could not be visited.

When a bugseed plant was found, a Global Positioning System was used to record the location. Thus the accuracy of the extant localities is very high and that of the historical localities (Figures 1-4) is lower. Digital photographs of the habitat and the plant were taken, and information regarding the habitat and associated species was recorded. The approximate size of the population was determined. If the population was relatively small ( $<100$ plants), I counted the total number of plants. If the population was large, I counted the number of plants in 25 randomly located quadrats of $1 \mathrm{~m}^{2}$ each, took the average, and multiplied it by the total area occupied by the population and rounded to the nearest ten.

Voucher specimens were collected and pressed for study at The Manitoba Museum, as confirmation of the species typically requires measurement and microscopic study of the seeds, especially when they are not fully ripe. In localities with large numbers of two or more bugseed species, it is possible that some errors were made when estimating the population size of each species, as not every single plant was examined. To minimize impact, I collected only part of the plant (i.e., one stem with a few seeds). Identifications were based on keys and descriptions in Mosyakin (2003).

The habitats of the species were grouped into one of two categories: natural areas not directly affected by humans and areas where humans have disturbed the soil in some manner. Natural areas were further divided into four categories: (1) inland active sand dunes and blowouts, (2) inland sandy hills and plains, (3) lacus- trine beaches and dunes, and (4) riparian sand banks and dunes. Anthropogenically modified areas were further divided into three categories: (1) sand and gravel pits, (2) sandy firebreaks, and (3) sandy roadsides.

\section{Results}

\section{Historical species and populations}

A review of the herbarium records and literature indicated that four species of bugseed were historically found in Manitoba: American Bugseed (C. americanum var. americanum), Hooker's Bugseed (C. hookeri var. hookeri), Pallas' Bugseed (Corispermum pallasii), and Hairy Bugseed (C. villosum). There were 20 historical populations consisting of 33 localities, most of which were American Bugseed (Table 2). Ten of those Bugseed populations (15 localities) were located again during the survey. The other 10 populations (18 localities) may be extirpated. The average collection date of the specimens at the possibly extirpated localities was 1948 (the median is 1946), so plants at these sites may have disappeared decades ago. Since Pallas' Bugseed (C. pallasii) was not encountered at any of the three sites where it historically occurred and has not been seen since 1960, it should be considered possibly extirpated in Manitoba. Grosshans et al. (2004) reported another bugseed species (Corispermum hyssopifolium L.) on beaches and exposed sand at Netley-Libau Marsh at the extreme south end of Lake Winnipeg. However, since no specimen was collected, the exact identity of this plant could not be confirmed; it was likely American or Hairy bugseed. Flooding in 2011 prevented closer examination of this area.

The rediscovery of historical populations using herbarium data can be difficult because of the lack of detailed location information. Although most labels list a town or city as a point of reference, the exact direction and distance from it are not always noted. Relocating a population with a broad locality description necessitates searching large areas to increase the chance of success. Thus it is possible that some localities may still have extant individual plants in quarter sections that were not searched during this study.

In some cases, examining historical literature can help provide information on the likely location of a population. For example, using such information I was able to deduce that the population of Hairy Bugseed collected by John Macoun in 1872 was very likely from the present-day Whitemud Watershed Wildlife Management Area, Edrans Unit, along Pine Creek, northeast of present-day Carberry. The label listed "Western Manitoba" as the locality, and this suggests that it was collected near St-Lazare or in the Oak Lake Sand Hills/Routledge Sand Hills. The current western boundary of southern Manitoba is just east of the 102nd meridian, but in 1872 Manitoba extended westward only as far as about the 99th meridian. At that time, "Western Manitoba" probably referred to the area near the Brandon Sand Hills. 


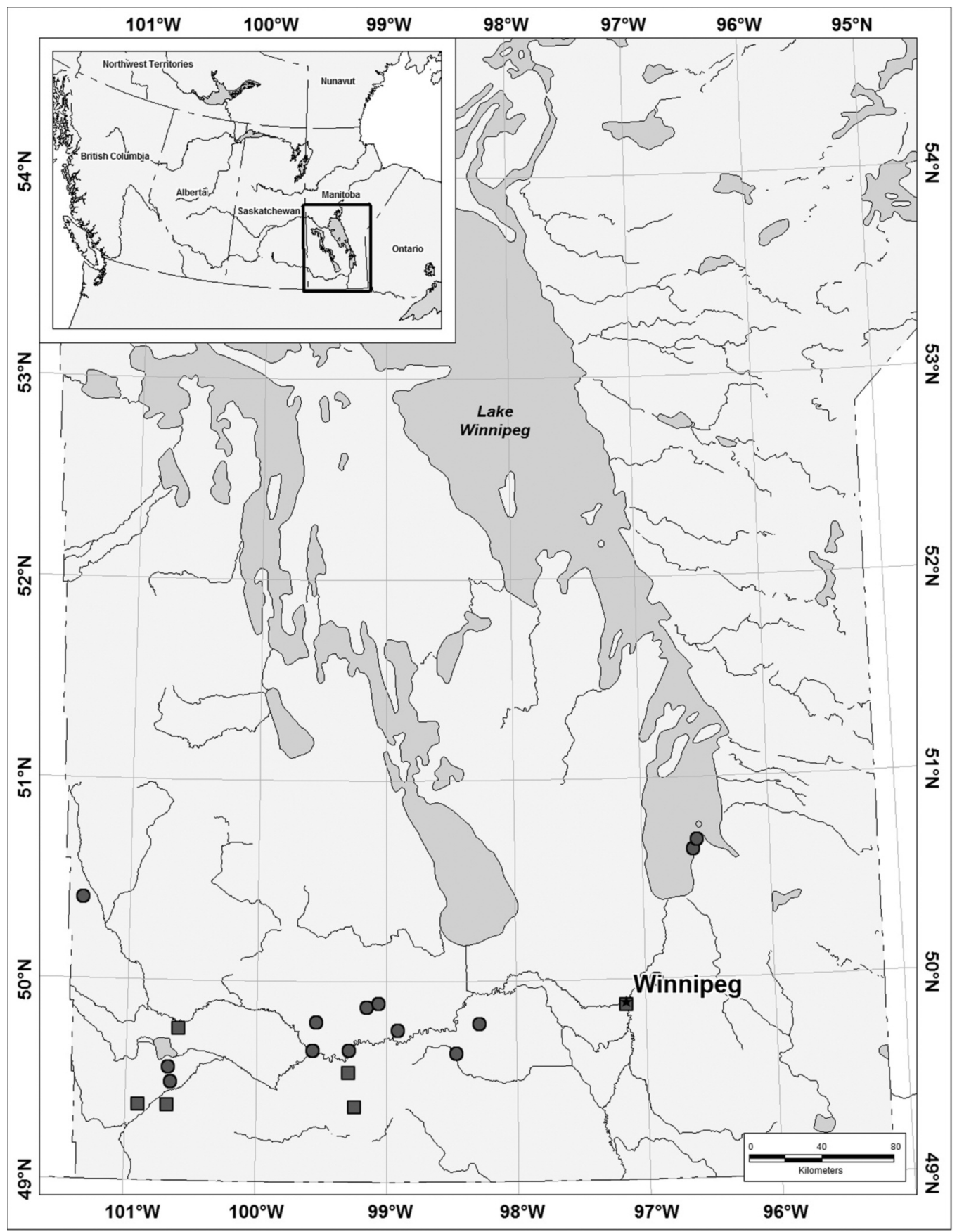

FIGURE 1: Distribution map of American Bugseed, Corispermum americanum, in Manitoba based on Canadian herbarium specimens and presence/absence surveys in 2010 and 2011. Circles indicate extant localities and squares historical ones. 


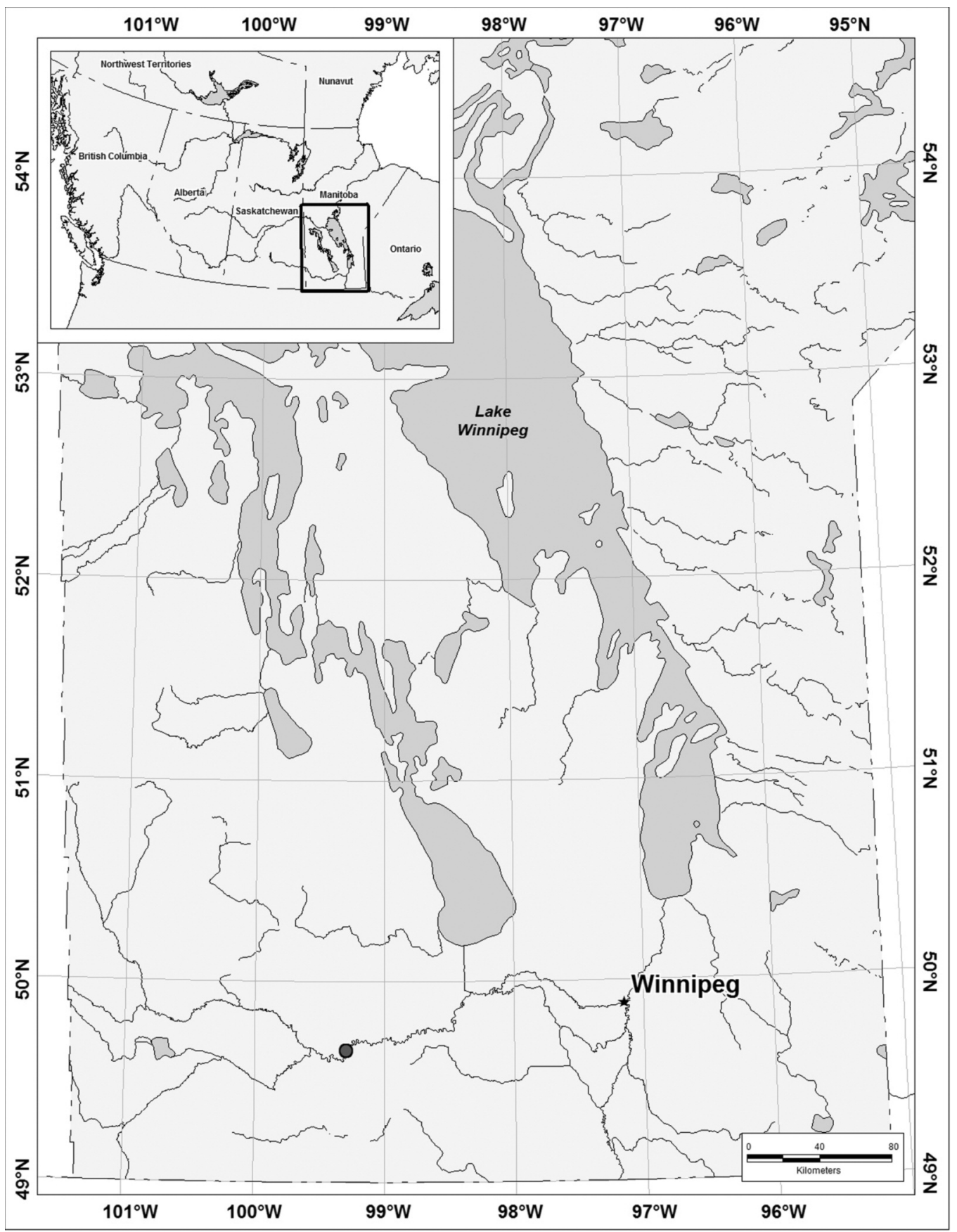

FIGURE 2: Distribution map of Hooker's Bugseed, Corispermum hookeri var. hookeri, in Manitoba based on Canadian herbarium specimens and presence/absence surveys in 2010 and 2011. The circle indicates an extant/historical locality. 


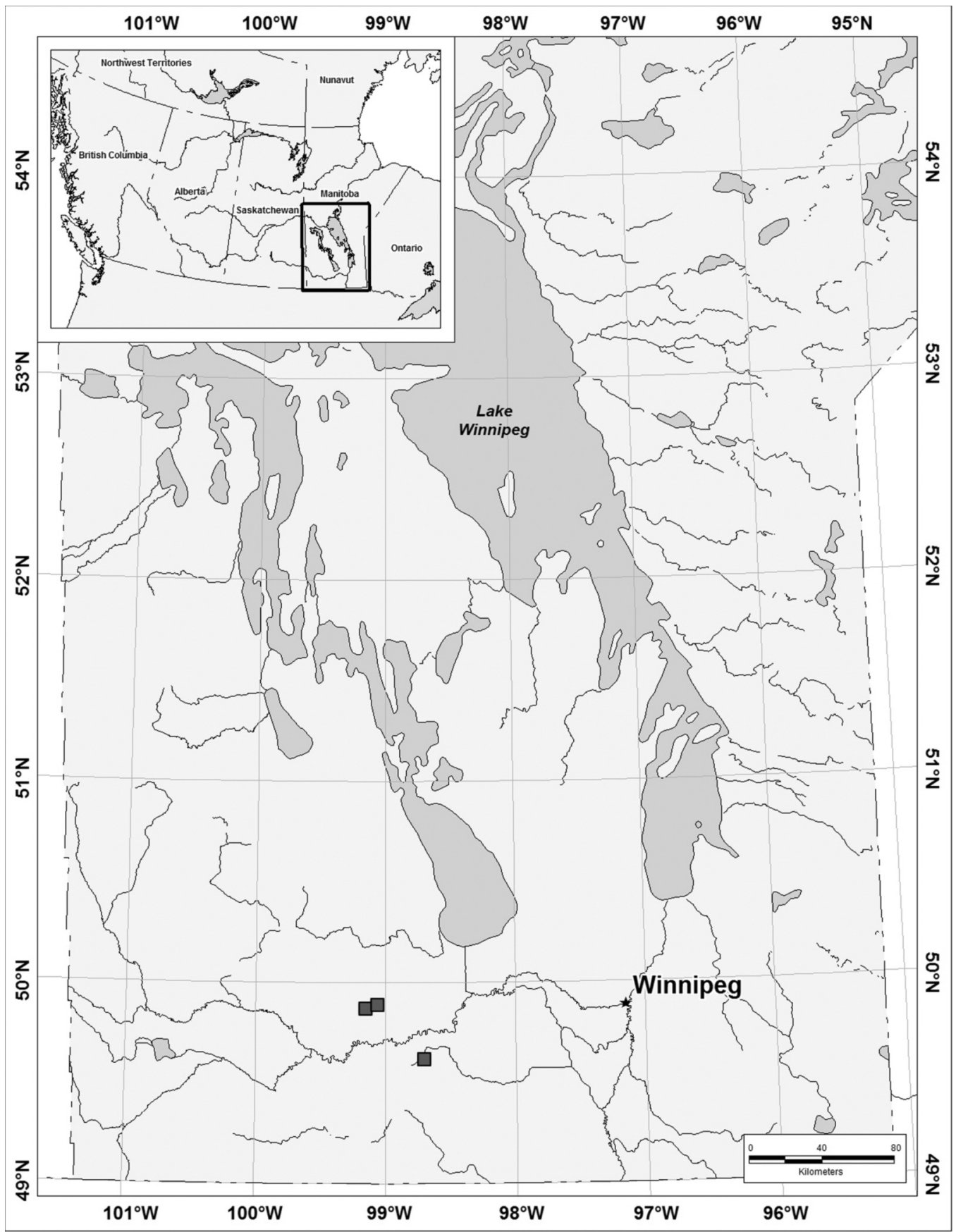

FIGURE 3: Distribution map of Pallas' Bugseed, Corispermum pallasii, in Manitoba based on Canadian herbarium specimens and presence/absence surveys in 2010 and 2011. No extant populations were found. Squares indicate historical localities. 


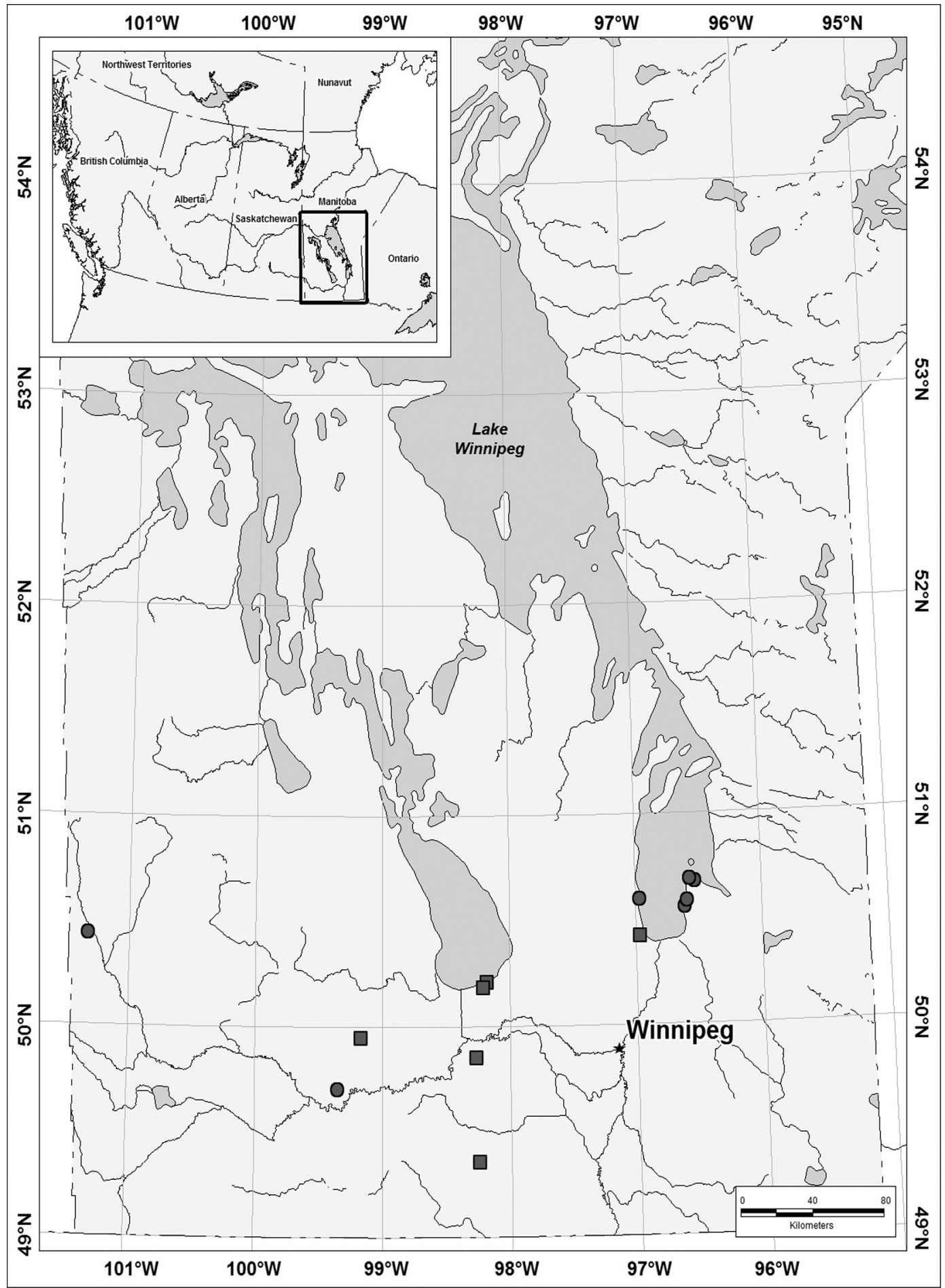

FIGURE 4: Distribution map of Hairy Bugseed, Corispermum villosum, in Manitoba based on Canadian herbarium specimens and presence/absence surveys in 2010 and 2011. Circles indicate extant localities and squares historical ones. 


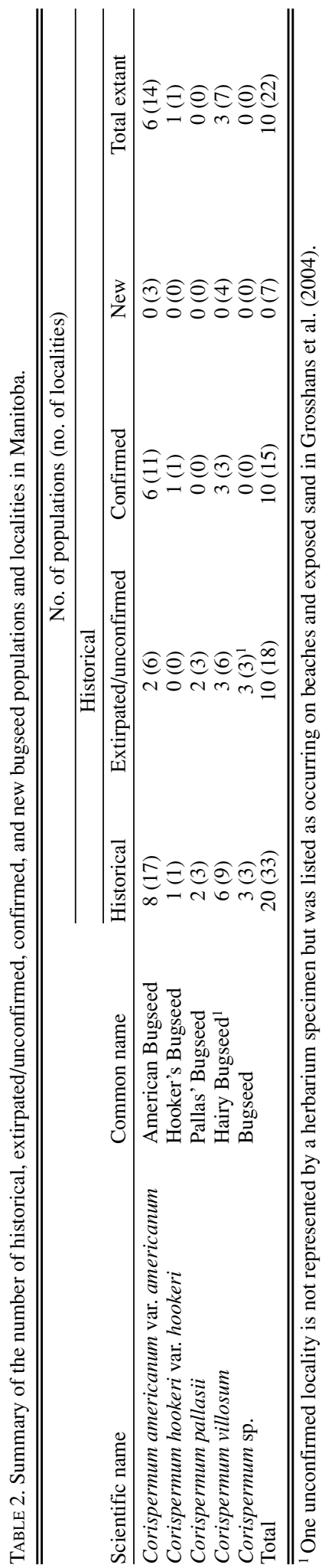

Examination of the field journals prepared by Macoun and his companion on the journey, Sandford Fleming, provided additional information that confirms this hypothesis. The journal clearly states that they encountered a region of sand dunes in 1872 near Pine Creek while travelling along the Carlton trail from Winnipeg to Edmonton (Fleming 1874). Historical maps of the Carlton trail show it passing through the northern portion of the Brandon Sand Hills across Pine Creek. Further, Macoun noted that White Spruce (Picea glauca) was common in this area. Since White Spruce is common in the Brandon Sand Hills but less common in dunes further west, the hypothesis receives additional support.

\section{Extant species and populations}

There are at least ten extant populations of bugseeds in Manitoba: three species occur in the Brandon Sand Hills, two along Lake Winnipeg, two in the St-Lazare Sand Hills, and one each in the Portage Sand Hills and the Lauder/Oak Lake Sand Hills/Routledge Sand Hills (Table 3). Seven new bugseed localities containing either American or Hairy bugseed were discovered during the surveys, but none were part of a new population. The most widespread and abundant species in Manitoba is American Bugseed, followed by Hairy Bugseed. The largest American Bugseed population was in the Brandon Sand Hills, and the largest population of Hairy Bugseed was along Lake Winnipeg. Most American Bugseed plants (71\%) occurred south of the 50th parallel, whereas most Hairy Bugseed plants $(92 \%)$ were north of it. Only one population of Hooker's Bugseed was found in the province and this was the historical population.

As the primary goal of this project was to determine the presence or absence of bugseed species at all historical sites, the quarter sections visited were not surveyed thoroughly enough to prepare accurate estimates of the population size or area of occupancy (Henderson 2009*). However, while surveying, I recorded the number of individual plants observed during the time available, and this provides a minimum size estimate for each locality. The total population size of bugseeds at all known localities is estimated to be between 9820 and 13060 plants. The population size estimates from the two largest populations, the Brandon Sand Hills and Lake Winnipeg, are the most likely to be inaccurate, as the entire dune area/beach could not be searched due to time constraints and accessibility issues, including flooding of some sites and military restrictions at Canadian Forces Base (CFB) Shilo. The Brandon Sand Hills, in particular, which have large active dunes, may house significantly larger populations of bugseeds than estimated. Further, the military maintains firebreaks, which churn up the sandy soil throughout the CFB Shilo range. Since I observed a large number of bugseed plants on just a small portion of the firebreaks that I examined, the number of individual plants at the base could be quite large. 
Bugseed plants were also recently found by Chris Friesen (personal communication, 2010) along the Assiniboine River in the Assiniboine Corridor Wildlife Management Area, which is also part of the Brandon Sand Hills. Since the Assiniboine River passes through a substantial amount of sandy habitat, bugseeds could be more abundant there than estimated. The catastrophic floods that occurred along this river in 2011 eroded the banks and exposed new areas of sand, which could, in the future, provide bugseeds with additional habitat.

Stevens et al. (1995) found that what they called Corispermum nitidum Kit. (which likely represents C. americanum) readily reinvaded riparian areas after a flood along the Colorado River. Further, Canadian herbarium labels indicate that some bugseed species have been found germinating in the sandy substrate dredged from the bottom of the Fraser River in British Columbia. This information suggests that some bugseed species are tolerant of submersion and can exploit areas of recently submerged sand. Thus my estimated population size for the Brandon Sand Hills is likely too low, perhaps by one order of magnitude. Nonetheless, this research provides a base from which to conduct future bugseed surveys should any of the species be nominated for national or provincial protection.

Hairy Bugseed was found at three of the beaches lacking historical records of bugseeds that were surveyed: Albert Beach, Grand Beach, and Lester Beach. No bugseeds were encountered at Patricia Beach or Winnipeg Beach. Three new American Bugseed localities were discovered near the Assiniboine Corridor Wildlife Management Area, Pratt, and Melbourne while I was searching for other rare species in the area.

\section{Habitats}

Most plants that were relocated (61\%) occurred in quarter sections that have been anthropogenically modified in some manner; $39 \%$ occurred in natural areas such as sand dunes (Table 4). Of the natural areas, the most common habitats were inland sand dunes, and lacustrine beaches and dunes along Lake Winnipeg. Sandy roadsides that cut into a stabilized dune were the most common anthropogenically modified habitat of bugseeds (Table 4). American Bugseed was more tolerant of disturbance than Hairy Bugseed, as $69 \%$ of the populations of American Bugseed occurred in anthropogenically modified areas compared to $45 \%$ of Hairy Bugseed (Table 4). Of the populations that are likely extirpated, $67 \%$ were described as occurring in natural habitats, $11 \%$ in anthropogenically disturbed habitats, and $22 \%$ had no habitat description on the label (Table 5). During the surveys, at least some native vegetation was located at $57 \%$ of the localities where bugseeds had likely occurred historically; $7 \%$ of the localities occurred near a water body and were flooded.

\section{Associated rare species}

There were 16 other species of rare plants found in association with bugseeds in various locations (Table 6). Two of the rare species are nationally rare and are 
TABLE 4. Habitat in each quarter section containing an extant Corispermum population in Manitoba.

\begin{tabular}{|c|c|c|c|c|}
\hline \multirow[b]{2}{*}{ Habitat } & \multicolumn{4}{|c|}{ No. of quarter sections ${ }^{1}$} \\
\hline & $\begin{array}{c}\text { Corispermum } \\
\text { americanum } \\
\text { var. americanum }\end{array}$ & $\begin{array}{l}\text { Corispermum } \\
\text { hookeri } \\
\text { var. hookeri }\end{array}$ & $\begin{array}{l}\text { Corispermum } \\
\text { villosum }\end{array}$ & Total \\
\hline \multicolumn{5}{|l|}{ Natural areas } \\
\hline Inland active sand dunes and blowouts & 6 & 1 & & 7 \\
\hline Inland sandy hills and plains & 1 & & & 1 \\
\hline Lacustrine beaches and dunes & 1 & & 4 & 5 \\
\hline Riparian sand banks and dunes & 1 & & 2 & 3 \\
\hline Subtotal & 9 & 1 & 6 & 16 \\
\hline \multicolumn{5}{|l|}{ Anthropogenically modified areas } \\
\hline Sand and gravel pits & 3 & & 2 & 5 \\
\hline Sandy firebreaks & 3 & & 1 & 4 \\
\hline Sandy roadsides & 14 & & 2 & 16 \\
\hline Subtotal & 20 & 1 & 5 & 25 \\
\hline Total & 29 & 1 & 11 & 41 \\
\hline
\end{tabular}

${ }^{1}$ Quarter sections rather than localities were chosen to analyze these data, as the habitats varied within some localities.

TABle 5. Habitat types of historical localities in Manitoba from which Corispermum has been extirpated or in which Corispermum could not be confirmed.

\begin{tabular}{|c|c|c|c|c|c|}
\hline \multirow[b]{2}{*}{ Habitat type } & \multicolumn{5}{|c|}{ "Localities } \\
\hline & $\begin{array}{c}\text { Corispermum } \\
\text { americanum } \\
\text { var. americanum }\end{array}$ & $\begin{array}{c}\text { Corispermum } \\
\text { pallasii }\end{array}$ & $\begin{array}{c}\text { Corispermum } \\
\text { villosum }\end{array}$ & $\begin{array}{l}\text { Corispermum } \\
\text { sp. } \\
\end{array}$ & Total \\
\hline \multicolumn{6}{|l|}{ Natural areas } \\
\hline Inland active sand dunes and blowouts & 3 & & & & 3 \\
\hline Inland sandy hills and plains & & 2 & 1 & & 3 \\
\hline Lacustrine beaches and dunes & & & 3 & 1 & 4 \\
\hline Riparian sand banks and dunes & 1 & & & 1 & 2 \\
\hline Subtotal & 4 & 2 & 4 & 2 & 12 \\
\hline \multicolumn{6}{|l|}{ Anthropogenically modified areas } \\
\hline Sand and gravel pits & 1 & & & & 1 \\
\hline Sandy roadsides & & & 1 & & 1 \\
\hline Subtotal & 1 & 0 & 1 & 0 & 2 \\
\hline No habitat description & 1 & 1 & 1 & 1 & 4 \\
\hline Total & 6 & 3 & 6 & 3 & 18 \\
\hline
\end{tabular}

protected by the federal Species at Risk Act: Smooth Goosefoot and Hairy Prairie Clover (Government of Canada 2011). Hairy Prairie Clover is also protected provincially by the Manitoba Endangered Species Act (Government of Manitoba 2011). Seven species are considered nationally rare (i.e., with a Wild Species Status code of 1,2, or 3) but are not legally protected while the other seven are rare only provincially (Canadian Endangered Species Conservation Council 2011). Sand Nut-sedge (Cyperus schweinitzii Torr.) was the rare plant found the most frequently with bugseeds (23 quarter sections). The Brandon Sand Hills contained the highest number of rare plants (12 species).

\section{Rarity status}

The current subnational rankings assigned to Corispermum spp. in Manitoba by NatureServe $\left(2010^{*}\right)$ and the Canadian Endangered Species Conservation Coun- cil (2011), as well as the new suggested ranks incorporating the information obtained in this study, are noted in Table 7. Four rank changes are recommended.

\section{Discussion}

This research suggests that all bugseed species in Manitoba are becoming rarer, as less than half of the historical localities still contain plants. This change appears to be due primarily to dune stabilization (Wolfe et al. 2000; Hugenholtz and Wolfe 2005) rather than outright habitat loss associated with cultivation or development, as $57 \%$ of the localities from which bugseeds have been extirpated or in which bugseeds were unconfirmed still contained some native vegetation. The research of Van Asdall and Olmstead (1963), who found that bugseeds decreased in density along a successional gradient of reduced light intensity and 


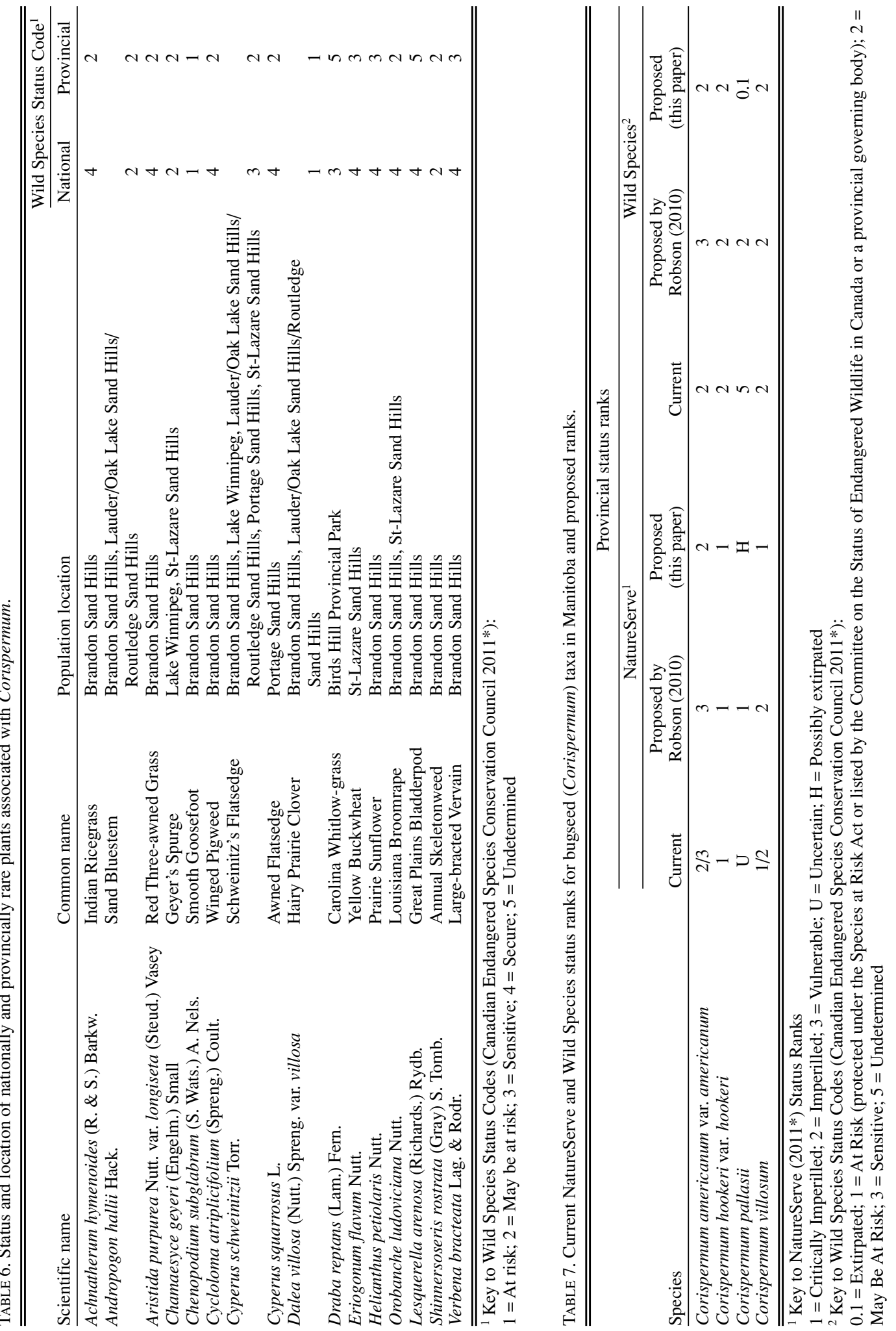


soil and air temperatures, supports this assertion. Burial by sand has been found to stimulate growth in bugseed plants, suggesting that, as dunes become stabilized, plants may become smaller and may be less able to compete with other species (Perumal and Maun 2006).

The fact that habitats of bugseeds at $61 \%$ of extant localities are anthropogenically modified suggests that bugseeds are becoming increasingly dependent on these habitats. Pavlovic (1994) notes that certain humancaused disturbances mimic natural ones closely enough that rare disturbance-dependent plants will occupy anthropogenically modified sites. The creation of sand pits and firebreaks and the grading of roadsides have become some of the only sources of disturbance left on the prairie landscape, now that ecosystem engineers like the Bison (Bison bison) have been largely exterminated and wildfires suppressed (Fox et al. 2012). Although bugseeds were found along railway tracks in the early 1900s, most of these areas are now completely covered by perennial and annual exotics. Thus some anthropogenically disturbed habitats for bugseeds have also been lost in the last century.

Some habitat for bugseeds has also been lost due to high water levels along Lake Manitoba and Lake Winnipeg. Since 1975, when the Nelson River was first dammed for hydroelectric power, lake levels have been regulated within a narrower range than occurred historically (Nielsen 1998; Grosshans et al. 2004). This regulation prevents low water levels and, in combination with isostatic uplift, has suppressed the growth of emergent vegetation. The result of the higher water levels and less vegetation is erosion of island and barrier beaches by wave action (Grosshans et al. 2004). Excessive runoff into both the Red River and the Assiniboine River during 2010 and 2011 increased water levels even further. As a result, many of the beaches and sandbars were flooded, resulting in less sandy habitat for the bugseeds that historically grew there.

No bugseed plants at all were found along the south shore of Lake Manitoba during this study. Along Lake Winnipeg, the largest locality remaining is a newly discovered cluster of Hairy Bugseed plants growing in the dunes at Grand Beach Provincial Park. A small cluster of Hairy Bugseed plants was found farther north, at Gimli, but no plants were observed at Matlock. The beaches and dunes at Victoria Beach and Albert Beach have eroded significantly (Nielsen 1998) and at present contain only small populations of bugseeds. High water levels on Manitoba's great lakes combined with storm surges have recently caused significant erosion of the beaches at the south end of the lakes where bugseeds occurred. Thus the loss of riparian and lacustrine habitat for bugseed on Manitoba's great lakes is due partly to natural causes (e.g., flooding) and partly human activities (e.g., alteration of lake levels and drainage).

Any future estimates of population size should take 7into account the annual nature of bugseed plants.
Research suggests that the seeds of bugseeds are capable of remaining dormant for decades, germinating only when conditions are favourable (Van Asdall and Olmstead 1963; Maun 1994; Zhang and Maun 1994). Maun (1994) found that bugseed germination tended to increase in years with high rainfall in dunes along Lake Michigan. Van Asdall and Olmstead (1963) noted that bugseed species may exhibit a biennial cyclic alternation of sparse and dense populations in areas where parent plants are buried with fruits attached on the surfaces of dunes where sand is deposited. Thus population size may fluctuate from year to year, depending on the weather and local disturbance patterns (Nunney 2002). A fluctuating pattern has been observed in other annual dune plants (Schat and Scholten 1985; Pavlovic 1994; Li et al. 2005; Robson 2006).

Based on the results of this survey, changes to several of the Manitoba status rankings are recommended. The NatureServe (2011*) rankings for C. americanum and C. villosum in Manitoba should be upgraded to "imperilled" and "critically imperilled," respectively, due to the small number of populations and individuals observed and documented declines in habitat size and quality. These ranks are rarer than recommended in Robson (2010), as the field surveys indicated that many of the historical localities no longer contain Corispermum plants. This underscores the importance of conducting revisitation surveys, as examining herbarium data only in this case resulted in an overestimation of the number of extant populations.

The status of Pallas' Bugseed in Manitoba is somewhat difficult to interpret. Mosyakin (2003) states that this species is native to northern Asia and probably native to North America. However, it is possible that it was wholly or partly introduced into North America from Europe (where it is not native). In Dolnik et al. (2011), Pallas' Bugseed was noted to spread as a "ruderal weed along railroads, and in urban, industrial and other anthropogenically disturbed sites" throughout northern Europe after it was released from horticultural collections of Siberian species in southwestern Germany in the early 19 th century.

In Manitoba, the three historical localities were in close proximity to the Canadian Pacific Railway, so it is possible that Pallas' Bugseed spread along railway corridors. Nowadays, most railway tracks in southern Manitoba are dominated by exotic ruderal plants, such as Summer Cypress (Kochia scoparia (L.) Schrad. ssp. scoparia), Lamb's-quarters (Chenopodium album L.), Wild Barley (Hordeum jubatum L.), Crested Wheatgrass (Agropyron cristatum (L.) Gaertn.), Russian Thistle, and Common Knotweed (Polygonum aviculare ssp. depressum (Meisner) Arcangeli). If Pallas' Bugseed did grow along railways in the past, it does not appear to occur there now. Thus, the NatureServe $\left(2011^{*}\right)$ rank for Pallas' Bugseed should change from "uncertain" to "possibly extirpated" and the Canadian Endangered Species Conservation Council Status Rank $\left(2011^{*}\right)$ should change from "undetermined" to "extir- 
pated". If this species is determined to be introduced rather than native, the status would then change to "exotic".

The longevity of bugseed seeds is potentially quite high, enabling them to tolerate burial and to exploit new bare areas of sand when they appear (Maun and Lapierre 1986). Bugseed seeds are common in the seed banks of stabilized dune areas, simply waiting for a disturbance in the vegetative cover (Pavlovic 1994; Leicht-Young et al. 2009). Therefore, measures that encourage the reactivation of some dunes in the province may be beneficial for bugseeds as well as other rare psammophilic species. Although traditionally conservation meant not disturbing a habitat, the adaptation of rare dune plants to periodic disturbance means that some disturbance is essential for their persistence (Pavlovic 1994).

The presence of two species of bugseeds on the firebreaks created throughout CFB Shilo is evidence of the beneficial effect of moderate soil disturbance on these species. The reactivation of stabilized dunes, potentially by reintroducing Bison, has been suggested as a way of increasing the available habitat for psammophilic plants and animals (Fox et al. 2012). Bison grazing combined with fire in the Nebraska Sand Hills was found to decrease bunchgrass cover (primarily Little Bluestem, Schizachyrium scoparium (Michx.) Nash), and increase annual forb cover, a result that would be likely to increase wind erosion (Pfeiffer and Steuter 1994). Although testing of the hypothesis that the activity of Bison in an enclosed area (as opposed to migratory activity) would benefit sand dune plants and animals still needs to be performed, the reintroduction of Bison into provincial parks containing sand dunes would be desirable for other reasons, including conservation of the natural fauna, restoration of a more natural disturbance regime, and as an additional ecotourism attraction. The reintroduction of Bison and possibly fire on public lands should be considered as part of the recovery planning for rare Canadian psammophilic species.

In summary, this research indicates that a substantial amount of habitat for rare psammophilic species like bugseeds has been lost over the last century. This habitat loss is due mainly to dune stabilization resulting from the loss of natural disturbances and from the flooding of lacustrine and riparian habitats. Thus conservation of these species will likely require a restoration of the traditional disturbances to which they are adapted.

\section{Acknowledgements}

Financial support for this research was received from The Manitoba Museum Foundation Inc. Thanks are extended to Vernon L. Harms for reviewing this manuscript. ECOSTEM Ltd. prepared the distribution maps.
Documents Cited (marked * in text)

Committee on the Status of Endangered Wildlife in Canada. 2010. Definitions and Abbreviations. Canadian Wildlife Service, Environment Canada, Ottawa. http:// www.cosewic.gc.ca/eng/sct2/sct2_6_e.cfm. (Accessed December 2011).

Henderson, D. C. 2009. Occupancy survey guidelines for prairie species at risk. Canadian Wildlife Service, Environment Canada, Saskatoon, Sask.

NatureServe. 2011. NatureServe Explorer: An online encyclopedia of life. Version 7.1. NatureServe, Arlington, Virginia. http://www.natureserve.org/explorer. (Accessed April 2012).

Thiers, B. 2012. Index Herbariorum: A global directory of public herbaria and associated staff. New York Botanical Garden's Virtual Herbarium. http://sciweb.nybg.org/science2/IndexHerbariorum.asp.

\section{Literature Cited}

Canadian Endangered Species Conservation Council (CESCC). 2011. Wild Species 2010: The General Status of Species in Canada. National General Status Working Group: 302 pp. http://www.wildspecies.ca/wildspecies2010 /home.cfm?lang=e (Accessed April 2012).

Chase, M. W., and J. L. Reveal. 2009. A phylogenetic classification of the land plants to accompany APG III. Botanical Journal of the Linnean Society 161: 122-127.

Dolnik, C., J. Peyrat, A. Volodina, and A. Sokolov. 2011. Neophytic Corispermum pallasii (Stev.) (Chenopodiaceae) invading migrating dunes of the southern coast of the Baltic Sea. Polish Journal of Ecology 59: 95-103.

Fleming, S. 1874. Report of progress on the explorations and surveys up to January 1874. MacLean, Roger \& Co., Ottawa, Ont.

Fox, T. A., C. H. Hugenholtz, D. Bender, and C. C. Gates. 2012. Can Bison play a role in conserving habitat for endangered sandhills species in Canada? Biodiversity and Conservation (Online First, February 15, 2012). http:// www.springerlink.com/content/1rl1637w84521w01/.

Government of Canada. 2011. Species at Risk Act. http:// laws-lois.justice.gc.ca/eng/acts/S-15.3/index.html. (Accessed January 2012).

Government of Manitoba. 2011. The Endangered Species Act. http://web2.gov.mb.ca/laws/statutes/ccsm/e111e.php. (Accessed January 2012).

Grosshans, R. E., D. A. Wrubleski, and L. G. Goldsborough. 2004. Changes in the emergent plant community of Netley-Libau marsh between 1979 and 2001. Delta Marsh Field Station Occasional Publication No. 4, University of Manitoba, Man.

Hugenholtz, C. H., and S. A. Wolfe. 2005. Recent stabilization of active sand dunes on the Canadian prairie and relation to recent climate variations. Geomorphology 68: 131-147.

Leicht-Young, S. A., N. B. Pavlovic, R. Grundel, and K. J. Frohnapple. 2009. A comparison of seed banks across a sand dune successional gradient at Lake Michigan dunes (Indiana, USA). Plant Ecology 202: 299-308.

Li, F.-R., L.-Y. Zhao, X.-Y. Zhao, T.-H. Zhang, and G. Li. 2005. The relative importance of pre- and post-germination determinants for recruitment of an annual plant community on moving sandy land. Annals of Botany 96: 1215-1223. 
Maun, M. A. 1994. Adaptations enhancing survival and establishment of seedlings on coastal dune systems. Vegetation 111: 59-70.

Maun, M. A., and J. Lapierre. 1986. Effects of burial by sand on seed germination and seedling emergence of four dune species. American Journal of Botany 73: 450-455.

Mosyakin, S. L. 1995. New taxa of Corispermum L. (Chenopodiaceae), with preliminary comments on the taxonomy of the genus in North America. Novon 5: 340-353.

Mosyakin, S. L. 2003. 18. Corispermum L. Pages 314-321 in Magnoliophyta: Caryophyllidae, Part 1. Volume 4 of the Flora of North America. Edited by the Flora of North America Editorial Committee. Oxford University Press, New York. http://www.efloras.org/florataxon.aspx?flora_ id=1\&taxon_id=108022.

Nielsen, E. 1998. Lake Winnipeg coastal submergence over the last three centuries. Journal of Paleolimnology 19: 335-342

Nunney, L. 2002. The effective size of annual plant populations: the interaction of a seed bank with fluctuating population size in maintaining genetic variation. American Naturalist 160: 195-204.

Pavlovic, N. B. 1994. Disturbance-dependent persistence of rare plants: anthropogenic impacts and restoration implications. Pages 159-193 in Restoration of Endangered Species. Edited by M. L. Bowles and C. J. Whelan. Cambridge University Press, New York.

Perumal, V. J., and M. A. Maun. 2006. Ecophysiological response of dune species to experimental burial under field and controlled conditions. Plant Ecology 184: 89-104.

Pfeiffer, K. E., and A. A. Steuter. 1994. Preliminary response of Sandhills prairie to fire and bison grazing. Journal of Range Management 47: 395-397.

Robertson, K. R., and S. E. Clemants. 2003. 39. Amaranthaceae Jussieu. Pages 405-456 in Magnoliophyta: Caryo- phyllidae, Part 1. Volume 4 of the Flora of North America. Edited by the Flora of North America Editorial Committee. Oxford University Press, New York. http://www.efloras .org/florataxon.aspx?flora_id=1\&taxon_id=10031.

Robson, D. B. 2006. A conservation evaluation of smooth goosefoot, Chenopodium subglabrum (Chenopodiaceae), in Canada. Canadian Field-Naturalist 120: 335-341.

Robson, D. B. 2010. An analysis of the distribution, ecology, and status of bugseeds (Corispermum) in Canada. Canadian Field-Naturalist 124: 246-255.

Schat, H., and M. Scholten. 1985. Comparative population ecology of dune slack species: the relation between population stability and germination behaviour in brackish environments. Vegetatio 61: 189-195

Stevens, L. E., J. C. Schmidt, T. J. Ayers, and B. T. Brown. 1995. Flow regulation, geomorphology, and Colorado River marsh development in the Grand Canyon, Arizona. Ecological Applications 5: 1025-1039.

Van Asdall, W., and C. E. Olmstead. 1963. Corispermum hyssopifolium on the Lake Michigan dunes: its community and physiological ecology. Botanical Gazette 124: 155-172.

Wolfe, S., and J. Thorpe. 2005. Shifting sands: climate change impacts on sand hills in the Canadian prairie and implications for land use management. Prairie Forum 30: 123-142.

Wolfe, S., D. R Muhs, P. P. David, and J. P. McGeehin. 2000. Chronology and geochemistry of late Holocene eolian deposits in the Brandon Sand Hills, Manitoba, Canada. Quaternary International 67: 61-74.

Zhang, J., and M. A. Maun. 1994. Potential for seed bank formation in seven Great Lakes sand dune species. American Journal of Botany 81: 387-394.

Received 8 January 2012

Accepted 22 March 2012 